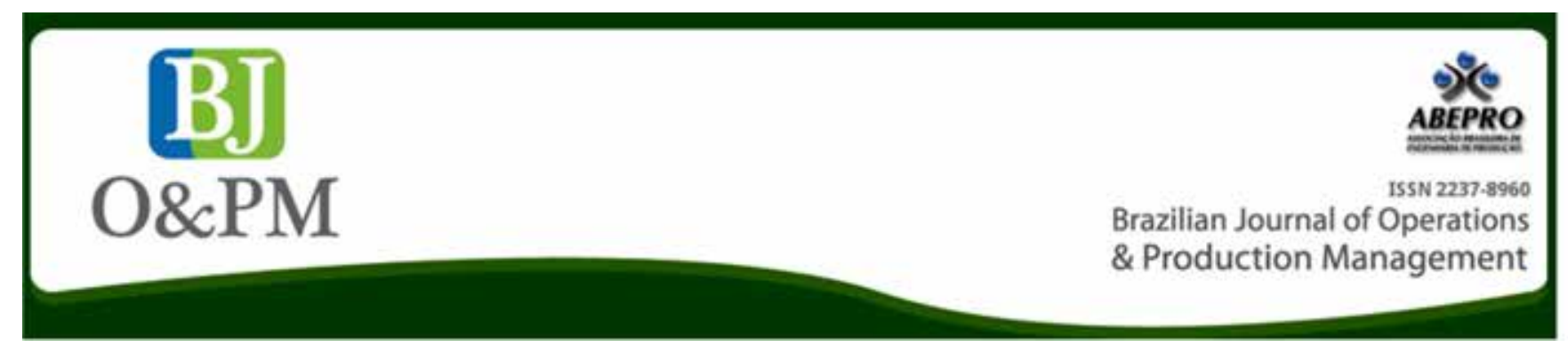

\title{
DIGITAL ART ON THE INTERNET: THE LIMITS OF THE BRAZILIAN LEGAL SYSTEM AND THE GLOBAL CONTEMPORARY THINKING
}

Wisrah Villefort

wisvillefort@gmail.com Fluminense Federal University UFF, Niterói, Rio de Janeiro, Brazil.

\begin{abstract}
This study aims at reaching the emerging global thinking around the relations of access to digital artistic content available on the internet. Through the appointments of the intersection between the knowledge on law, anthropology, philosophy, physics, and art, which are organized in a multidisciplinary way, the present scientific narrative is build. Initially, a brief history of the idea of constructing copyright in the global context is presented. Subsequently, the digital object is analyzed as material to produce art in the contemporary context. Then, the post-internet cultural phenomenon is observed, so that the current Brazilian Copyright Law System can be inquired due to its limits and openings. Finally, the 'Creative Commons' is presented analytically in the face of current demands following the contemporary understanding around copyright.
\end{abstract}

Keywords: Copyright Law; Digital Art; Post-internet; Creative Commons. 
Brazilian Journal of Operations \& Production Management

Volume 15, Número 3, 2018, pp. 405-412

DOI: 10.14488/BJOPM.2018.v15.n3.a7

\section{INTRODUCTION}

Creativity is the highest human attribute and the earliest records of its expression are linked to those of humanity itself. For example, the cave paintings in Europe and Indonesia, and the sculptures of the Paleolithic Period of Prehistory are prior to writing as it is known today (Santos, 2009).

The emergence of the idea of a right of protection to the product of human creativity, however, takes shape only from the historical period that has been called the Modern Age. In 1454, Johannes Gensfleisch zur Laden zum Gutenberg created the moving characters and a printing model that would revolutionize bibliographic reproduction forever. Gutenberg's press consisted of 3D types made of metal so they were tough and could be reused several times. These embossed metallic letters were painted, hand-organized, and pressed against the substrate which would receive the impression to form words, columns, and pages. Before that, in Europe, bibliographic reproductions were made as manuscripts in a very small scale. Gutenberg actually only enhances a technique already present in the Chinese culture since the seventeenth century that used, however, wooden types (Santos, 2009).

The improved model enables the reproduction of written works on a significantly larger scale when compared to the possibilities of the already existing scenario of reproduction by manuscripts. The consequence of this advance that matters the most to the present study is that it opens the possibility of commercial exploitation of this good. It was only from this possibility that one begins to feel the social need to legislate around this printed immaterial product.

Thus, to control the reproductions a system of printing privileges is initially set up. It was this system that determined in Europe who could reproduce the impression, what works could be reproduced, and for how long those privileges lasted. According to Santos (2009) The criteria for these initial privileges were rather subjective and non-homogeneous. In short, the monarchs were those who gave printers such privileges through political discernment.

The understanding around the protection of these rights evolves from this initial system and gradually reaches higher levels of complexity as new questions arise around the theme. Particularly in France and England, the notion of copyright has reached levels of complexity that have not been observed in other parts of the European continent at that time. However, these two lines of thought make up summarily distinct notes.

In England, in 1557, from a Royal Charter that reinforced the exclusive right to publish books to Stationer's Company and its authority over practitioners of the books trade, by
Maria Tudor and Philip II, the history of copyright begins. This regime protects the right of the publisher to the detriment of the author, and the principal right protected is the reproduction of the copies. Years later, the droit d'auteur, which means the right of the author, is the result of norms approved by the Constituent Assembly in France in 1791 and 1793, as a result of the end of the privileges of the publishers from the French Revolution. This regime is the reverse of copyright; it is concerned with the creativity of the work to be copied and the moral rights of its creator, as pointed out by Santos (2009). The present study, however, is not concerned with detailing the genesis and historical evolution of copyright.

It attempts, otherwise, to introduce and question the limits of this systematics of the current legal context of the Brazilian copyright in its relationship with the panorama of contemporary digital art present on the internet. In the end, new thoughts on this problem are pointed out from the Creative Commons system, presenting it, not as a solution, but as a possibility.

\section{DIGITAL OBJECTS AS MATTER AND MATERIAL}

As personal computers become more accessible, from the 1980 s and 1990 s, the possibility of experimentation with computational resources is widened. These experiments enabled the production and recording of a non-physical matter, the digital object. If in the Paleolithic Period man used stones and bones to materialize his creative mental capacity, it is evident that contemporary man uses computers and software to produce art. Machado (2007) notes that art is made with the means of its time.

It should be noted that, according to the studies of Kallinikos (2010), it is understood as a digital object the production of immaterial digital technologies, devices and artifacts, including - but not limited to - music, video, and image. However, grouping distinct media under the same title requires the development of a dissertation around its convergent characteristics.

Initially it is important to understand that, unlike conventional physical artifacts, the digital object is editable by nature. This editability assumes several protocols. It can occur, for example, only by rearranging the elements by which the object is composed, excluding some of those elements or adding new ones. Thus, the digital object is potentially in a continuous modification process.

Because it is editable, the digital object is also replicable. This replicability implies in a total loss of the notion of the difference between the original file and its copy. In his essay "The Work of Art in the Age of Mechanical Reproduc- 
tion", the philosopher Walter Benjamin, in 1936, already previewed the lack of uniqueness of art objects as a consequence of the introduction of industrial techniques for the artistic field. This notion of reproduction starts from the intention of the authors themselves who want, for example, to distribute copies of a digital album of songs to different parts of the world. Such technology also causes the term reproduction to lose the core of its meaning since there is no copy in the literal sense of the word. What is reproduced is the mathematical formula of the image, the text or the sound. Copy in the digital context has a distinct connotation of what is understood in the context of classical works of art, for example as explained above, because the initial intent is different.

As in the case of the editability, the replicability of the digital object is not the only characteristic of the object, but a characteristic factor of the digital culture itself. Travisani (2010) states that this replicability movement must be seen as an artistic manifestation in itself, proper for media convergence. It is pointed out that, as Manovich (2001) states, the remix is the best metaphor for understanding the new media. Such notes incite the perception of replicability not only as a technical possibility but as a particular thought of digital actions.

By being editable and replicable, the digital object has the ability to be present everywhere and at any time; this characteristic is called ubiquity. Thus, a work of digital art has ubiquitous force. This potential omnipresence of an art object forces the expansion of classical notions of space and time - pillars of classical thinking around the object of art as something unique, absolute, and sovereign. Ubiquity brings the reflection, then, not only around the physicality of the digital object itself, as raw material to produce art, but also around the nature of its exhibition, its existence, and its dimensions. The ubiquity of the digital object is possible because its formative characters are codes and these are the basis of today's cultural telematics. In this way, there is no real fixed location for that object; they can be shared infinitely and therefore be suitable for another use. By being available in a network environment and supported by a database, this object can potentially be appropriate and replicated. In addition to the questions of copyright, these characteristics constitute a true revolution in terms of artistic production.

The understanding of art as an information system predates the spread of the internet as it is known today. Notable contributions to the introduction of this thought were the feats of artists Marcel Duchamp and Andy Warhol. Notably, those artists broke with the romantic figure of the artist-artisan in the context in which the value added to a work of art was deduced from his emotional inspiration, a thoughtful present even within the philosophy of modern art. The "doing by hand" is abandoned and gives room to the possibility of working with signs. By moving ordinary images into the artistic context, Duchamp and Warhol introduce and consolidate the possibility of art created from reason and logic within an information system, and then value the idea; pointing to a philosophical-artistic break. These changes go back to the oldest questioning of the artistic context: "what is art?".

This philosophical breakup can be exemplified through the thoughts of Arthur Danto and Anne Cauquelin. Danto (2006) proposed a system of validation of what is considered a work of art through its existence within what he calls the "world of art". The world of Danto is composed of museums, galleries, artist, spectator, curator, etc. In this way, it is art that is created by an artist, since it is exposed in a space destined to art to be seen by an audience that understands that as art. This institutional idea of the art system is refuted by Cauquelin (2005), who states that exposing an object of art means to name it, giving the artist autonomy to decide what art is and when it is art. Cauquelin's ideas synthesize the philosophy of contemporary art, although they find resistance in some sectors of the artistic community.

That being said, it is clear that the digital art scene touches on contemporary art itself. The philosopher Anne Cauquelin points out that the system of contemporary art is the information system and this characterizes its multidisciplinarity. This justifies the proximity between art, science, and technology presented here in the construction of a dissertation around the artistic object. Thus, beyond production, the digital art revolution reaches its distribution and the entire art system. Anyone with access to the privileges of digital technologies can create and make an intellectual work public. It gives the possibility of autonomy to artists, to a certain degree, that does not depend on hegemonic means to display and distribute their own productions.

\section{THE POST-INTERNET PHENOMENON}

Besides art, the post-internet context presents a social condition in general, where the perception of connection to the Internet surpasses the status of novelty and reaches that of banality. The omnipresence of information is the driving force of society's dependence on the internet connection and this is what worsens the perception of being connected. Lovink (2016) points out that the automation of the collective sensation of connectivity takes the Internet to the level of platitude. He understands that, increasingly, one does not perceive to be connected and the challenge with regard to the internet has become that of not being present. The researcher notes that only the desire to be offline has brought the awareness of that prior connectivity. To disconnect is the contemporary conscious movement that has to be made 
Brazilian Journal of Operations \& Production Management

Volume 15, Número 3, 2018, pp. 405-412

DOI: 10.14488/BJOPM.2018.v15.n3.a7 when it comes to networking; thus, it has to be part of a decision, often associated with an idea of rest and balance.

In this context, the possibility of being disconnected even reaches the level of privilege. In many relationships, being online is a tacit need - for example in between students and university, workers and some companies where the precondition of remote communication makes it difficult not to be connected. In this way, the growth of Internet access transforms the relations of distribution and reception of information, including artistic intellectual works. This is associated with the fact that arts have appropriated the technological apparatus that is contemporary to their production processes and procedures and that sets the scenario presented here. More people have access to images and sounds through their computers and cell phones connected to the internet in recent times than in physical environments such as museums, galleries, and cultural spaces as it used to be.

The gallery is no longer the main art exhibition space; the internet is. This sets it incidentally as the main form of audiovisual appreciation of society these days, thus setting up an art scene produced by the computer and to be displayed on the computer over the internet. The possibility of a work of art being completely digital, allied to the possibilities opened by the internet, allows the display of an artistic object to be intentionally digital.

The term "post-internet", however, was first used by artist Marisa Olson in 2006 at a panel discussion hosted by Rhizome, a non-profit organization that offers discussion platforms and exposure to new media art. The foundation of Olson to characterize the product of her work through the neologism was the perception of her artistic process to be associated with the possibilities of the internet as an omnipresent network. Later, the nomenclature is developed by Gene McHugh in his critical blog "Post Internet". The blog was active between December 2009 and September 2010 and subsequently organized into a printed book that presents the blog posts in a chronological order under the title "Post Internet: Notes on the Internet and Art".

Olson and McHugh are credited with pioneering the introduction and development of the post-internet context idea in art. However, the idea that a post-network culture would exist was already a thought of Manovich (2001) before the term was coined. Although, it is interesting to note that a little more than a decade after the beginning of post-internet terminology to distinguish an artistic modality, many of the artists who initially set out to work on the subject suggest a reconsideration of its meaning.

Italian curator Visconti points out that, in the last decade, there was a gradual emptying of the term meaning, which has led to a banalization of its use. As a consequence, post-internet is often used simply to define any artistic project that uses digital technologies. For these reasons, she believes that a process of rejection to the term has begun by the artists. Visconti points out that it is important, on the face of it, to recognize post-internet as an artistic phenomenon, but to advance from that towards a production in order to abandon stylistic generalizations and challenge the materiality biases of digital procedures.

Vierkant (2010) states that it is important to understand post-internet as an artistic moment. This allows the image of the digital work to be placed in the same position as the objects in galleries and museums; thus, ontologically, those images are objects themselves. Despite the fact that there is no dimension of the scope of a digital artistic object and the way it changes in this distribution process, the recent possibility of greater autonomy and independence of the artist in the production and exhibition of his works is undeniable. However, even the traditional art system was affected by the spread of art through the internet. For example, since 2009 the Venice Biennale has an online pavilion of digital works and the world's largest art biennial, The Wrong, is mostly digital and happens on the internet.

\section{THE CURRENT PANORAMA OF AUTHORIAL LAW IN THE BRAZILIAN LEGAL SYSTEM}

In Brazil, the Law No. 12.965 of 2014, the Brazilian Civil Rights Framework for the Internet, is the instrument that proposes to regulate the use of the World Wide Web. The institute places access to the internet in the status of citizens' right by indicating principles, guarantees, rights and duties for the user of the worldwide computer network, as well as determining the State's performance. However, with regard to the protection of intellectual property of works available on the Internet, the aforementioned Law indicates that it will continue to be subject to the applicable copyright legislation. Thus, the Constitution of the Federative Republic of Brazil and the Law No. 9.610 of 1998 (Brazilian Law on Copyright and Neighboring Rights) are the legal provisions that prelude the understanding on what should be protected in the relation of the creation and use of the artistic work in the online environment. Bringing principles already present in the Federal Constitution of 1988 and reflections in the positive legislative system of other nations, the LDA - as the Brazilian Law on Copyright and Neighboring Rights is shorted in Portuguese - is concerned to guarantee to creators their intellectual property protected based on moral rights. With that said, it is important to analyze what is related to copyright protection in the Federal Constitution (Brasil, 1988):

Article 5. All persons are equal before the law, without any distinction whatsoever, Brazilians and foreigners residing in the country, being en- 
sured of inviolability of the right to life, to liberty, to equality, to security, and to property, on the following terms: (CA No. 45, 2004)

(...)

XXVII - the exclusive right of use, publication or reproduction of works rests upon their authors and is transmissible to their heirs for the time the law shall establish;

XXVIII - under the terms of the law, the following are ensured:

a) protection of individual participation in collective works and of reproduction of the human image and voice, sports activities included;

b) the right to authors, interpreters, and respective unions and associations to monitor the economic exploitation of the works which they create or in which they participate;

(...)

It is observed that the guarantees presented above are concerned with ensuring the protection of the author over the potential publication. Coelho (2006) points out that the current Brazilian protection to intellectual property system is close to the French droit d'auteur, because of the configuration of the Brazilian legal system. In fact, it is affiliated with the Romanesque legislative tradition. It is interesting to note that, during the evolution of this system, at no time does Brazilian law approach the idea of copyright that tangents the English thought. Regarding the provisions of the 1988 Constitution, it is understood that, by including, for example, the prerogative of publication exclusivity of the work of the authors' right, besides guaranteeing to creators the faculty of offering or not their work to the public, the aspect morality of copyright is constitutionalized. Bringing the questioning around what is a work of art for the legal scope and thinking specifically about the digital work, see the orientation of Article 7 of the LDA:

Article 7. The intellectual works that are protected are creations of the mind, whatever their mode of expression or the medium, tangible or intangible, known or susceptible of invention in the future (...).

The above device defines the creations of the mind and the positive opening for future creations of matter and platform as intellectual work. It follows, then, that works of art that are made with a digital object and are available on the internet are protected by the Brazilian legal system. Thus, in the Brazilian system, copyright infringement is a criminal subject. Having said that, what the Brazilian penal system preconizes in terms of the violation of these rights has to be observed.
In this regard, Article 184, Paragraph 3 of the Brazilian Criminal Code, introduced by Law 10.695/2003, deals with the violation of the intellectual property that is protected and similar to the rights through the use of new technologies. Correspondent to such provisions, these crimes - that are punishable from two to four years and a fine - consist of "offering to the public, through cable, optical fiber, or satellite, waves or any other system that allows users to select a work or production for receipt thereof in a present time and manner defined by the offeree, for a direct or indirect profit of the offeror, without express authorization from the respective author, artist, interpreter, performer, phonogram producer, or respective representative."

Having displayed that, the reflection that interests the present study the most is the difficulty in controlling the artistic content present on the internet and, consequently, its use, which is enhanced by the global character of the internet, despite the fact that this paper deals with the Brazilian panorama. Faced with this extraterritorial character of the internet and its content, it is demanded of the legislation that it considers international effectiveness. The global dynamics of this access has modified the interconnected society in all aspects; however, it would be reductive to imagine that there is a pattern of intentions on the part of the authors as to the use of the works of their creation. In this sense, the legislator leaves an opening in the Article 49 of the LDA, as it can be observed below:

Article 49. Author's rights may be wholly or partly transferred to third parties by the author or by his successors, in a universal or individual transfer effected in person or through representatives with special powers, by licensing, concession, assignment or any other means recognized by law, subject to the limitations set forth below:

I. Total transfer shall comprise all the author's rights with the exception of his moral rights and rights expressly excluded by the law;

II. The total and final assignment of rights may be effected only by contractual provision;

III. in the absence of written contractual provision, the maximum period of transfer shall be five years;

IV. unless otherwise specified, assignment shall be valid only in the country in which the contract has been signed;

V. the assignment shall be valid only for the modes of exploitation existing on the date of the contract;

VI. in the absence of any mention of the mode of exploitation, the contract shall be interpreted restrictively, and understood to be limited to the mode of exploitation that is indispensable for the fulfillment of the purpose of the contract. 
Brazilian Journal of Operations \& Production Management

Volume 15, Número 3, 2018, pp. 405-412

DOI: 10.14488/BJOPM.2018.v15.n3.a7
It is understood that, in granting the possibilities set forth in the Article 49 of the LDA, the legislature not only maintains the moral right of authorship but also recognizes the impossibility of the positive law to foresee all social transformations and demands within the complexity of any evolving society. The positivation of a legal institute according to the format of the law starts from the premise of standardization of legal facts. Despite the fact that this makes legal security to possible future situations predicted, it excludes all others that were not previously thought and, in this sense, it is essential to have an institution that ensures the unforeseen and predicted at the same ontological status within that same law. Likewise, ensuring the individuality of the holder of a right is in full agreement with the general understanding of the Brazilian Constitution, ensuring freedom in a broad and amplified way.

\section{THE GLOBAL THINKING AND CREATIVE COMMONS}

The way the digital object is distributed and available on the internet, combined with the edibility, replicability and ubiquity of this object allows a digital artwork to be not only a product but also a matter for new creations. Appropriation and remix are techniques established as a tool of contemporary art. What may seem to be worrying from the point of view of intellectual property protection is, in fact, for many artists, creative power. Looking at the Jogging collective's text "Redefining Exhibition in the Digital Age", McHugh (2011) identifies how radically the Internet has changed the way the information is distributed, to the point of changing the way artists portray their work. He believes that the digitization of the art system, its exhibition platforms, and its audience go beyond copyright notions because they shake up the pre-established relations of power. By seeing creative power of material in theoretically finalized art objects and going through the existent relations of power, a thought regarding intellectual property has been consolidated. In several cases, it has become interesting not only to provide works for third-party uses but also to verbalize the licensing of such use.

A good example of the materialization of this emerging thinking that intents to go outside of the judicialization of intellectual property is the Creative Commons, a non-profit organization that allows one to share intellectual works through free legal instruments. The idea of this system was developed by Lawrence Lessig, a professor at Stanford University in the United States of America in 2001. It was aimed to expand the dynamics and quantity of intellectual works available to the public, allowing the creation of works from previous artworks and share them. This sharing is organized by the use of licenses under flexible situations. The public licenses are legal licenses as well and can be used by any person or entity so that their intellectual products are made available openly.
Although it has appeared in the United States first, the Creative Commons has a global character. By this factor, it is presented by the present study as a possible thinking model for the digital art issues available on the internet, which tangents the global thinking indicated in this study, due to its extraterritorial character. In Brazil, the CC - as Creative Commons is shorted - is coordinated by the Technology and Society Center of the Law School of the Getúlio Vargas Foundation in Rio de Janeiro and it is supported by the Ministry of Culture. Authors of any intellectual work that may be protected by copyright may license their works within the limits of the license chosen. It is important to emphasize that licensing a work under a CC license is not an act contrary to the copyrights of the current national legislation; it is rather an act legitimized by the LDA, particularly by its Article 49 . Thus, in Brazil, violating a Creative Commons license is the same as violating copyright, as it is protected by the current copyright law.

It is clear that making a work available under a Creative Commons license is not synonymous with giving up the copyright, but having autonomy to decide what rights to reserve of that work, according to the author's decision and the act of autonomy of the intellectual creator. It is important to differentiate the granting of patrimonial rights from the licensing proposed by Creative Commons. In the words of Santos (2009):

\footnotetext{
Concession is a business of transferring patrimonial rights of a temporary nature, usually not exclusive and not precarious. Licensing may or may not be precarious, in the sense of admitting its unilateral resilience by the author at any time. The concession moves away from licensing when it takes care of the exclusivity of exploitation and precariousness. Creative Commons is a license, as the copyright holder continuous to be the author, and not exclusive because the use can be made by anyone.
}

See, then, the types of license available by Creative Commons and the explanation given by the organization itself on its website:

a) Attribution (by) All CC licenses require that others who use your work in any way must give you credit according to your request, but not in a way that suggests that you endorse them or their use. If they want to use your work without giving you credit or for endorsement purposes, they must get your permission first.

b) ShareAlike (sa) You let others copy, distribute, display, perform, and modify your work, as long as they distribute any modified work on the same terms. If 
they want to distribute modified works under other terms, they must get your permission first.

c) NonCommercial (nc) You let others copy, distribute, display, perform, and (unless you have chosen NoDerivatives) modify and use your work for any purpose other than commercially unless they get your permission first.

d) NoDerivatives (nd) You let others copy, distribute, display and perform only original copies of your work. If they want to modify your work, they must get your permission first.

It is important to say that the licenses can be combined. Thus, for example, a work can be licensed under the by-nc combination. This means that one can allow others to remix, adapt, create from the work made available for non-commercial purposes and that the derivative works must give credit to the original work, may not be used for commercial purposes, and do not have to be licensed under the same terms as the first work.

The simplest legal way to acknowledge the proposal of Creative Commons is to understand the instrument as a contract between the holder of the intellectual property and those who wish to use the work. It is to be noted that this contract finds legal support in the Brazilian legal system itself and the praise given to the opening given to this relationship through Article 49 of the said Law is strengthened. Thus, the present study presents the CC not as a solution to possible questions regarding the relations of copyright but, rather, as a possibility of a reference to a flexible and contemporary legal philosophy, in the way of a positive right that does not have as source only the legal sphere, forming a multidisciplinary construction of knowledge.

\section{FINAL CONSIDERATIONS}

The present study proposed to counter the Brazilian legal system and the contemporary international thinking regarding the relations that orbit around the access to artistic contents available on the internet. Starting from a brief history about the construction of the idea of protecting intellectual property, it is evidenced that this thought proceeds from the possibility of commercial exploitation of human creativity. Beyond the law and the art, this paper tries to put in the same level the disciplines that propose to deal with the transformations driven by the dissemination of digital technologies in artistic processes and procedures in a temporal context where the internet has reached the status of banality. By presenting the digital object as a tool and material for art and contextualizing it from the power of its network distribution, the study accompanies the under- standing of the philosopher Anne Cauquelin, who points out that the substrate of contemporary art is information. Thus, an information network sets up a communication regime and the system presented in this article is the contemporary phenomenon called post-internet. This system will then provide significant and irreversible changes in the relation human-space-time-consumption and, consequently, in the relation of everything with art; in addition to the individual transformations that each of these novelties previously brings.

At the same time, the materiality of the digital object approximates the knowledge of art, technology, and science and the concept of post-networking brings art, anthropology, physics, and philosophy together. The dissolution of the barriers between such knowledge materializes the multidisciplinarity of the thought around a new phenomenon that points the global thought of the contemporaneity. By presenting the Creative Commons, it is simply intended to point out the possibility of an open thought regarding the intention of dealing legally with contemporary transformations. It is believed that the legislators themselves, when making Article 49 of the LDA, admitted the impossibility of predicting future innovations that demand a response from the current system.

Understanding art as information and perceiving its ubiquitous potential constitutes the instability to which the control systems are submitted in the current panorama. This scenario forces the revision of classical theories and expands pre-established notions between polarizations such as permanent-ephemeral, single-multiple, present-absent, author-publication, etc. The movement of different disciplines around the study of the same topic finally presents, propels the dissolution of the barriers that separate the knowledge, and possibly presents the main characteristics of any contemporary thought: multidisciplinarity.

\section{REFERENCES}

Brasil (1988), Constituição da República Federativa do Brasil de 1988, Casa Civil.

Brasil (1998), Lei no 9.610, de 19 de fevereiro de 1998. Altera, atualiza e consolida a legislação sobre direitos autorais e dá outras providencias, Diário Oficial da União, Brasília.

Brasil (2003), Lei no 10.695, de 1ㅇ de julho de 2003. Altera e acresce parágrafo ao art. 184 e dá nova redação ao art. 186 do Decreto-Lei no 2.848, de 7 de dezembro de 1940 - Código Penal, alterado pelas Leis nos 6.895, de 17 de dezembro de 1980 , e 8.635 , de 16 de março de 1993, revoga o art. 185 do Decreto-Lei no 2.848 , de 1940, e acrescenta dispositivos ao Decreto-Lei no 3.689, de 3 de outubro de 1941 - Código de Processo Penal, Diário Oficial da União, Brasília. 
Brasil (2014), Lei no 12.965, de 23 de abril de 2014. Estabelece princípios, garantias, direitos e deveres para o uso da Internet no Brasil, Diário Oficial da União, Brasília.

Cauquelin, A. (2005), Arte contemporânea: uma introdução, Martins Fontes, São Paulo, SP.

Coelho, F. U. (2006), Manual de Direito Comercial, 14. ed., Saraiva, São Paulo.

Danto, A. C. (2006), A Transfiguração do Lugar-Comum, Cosac \& Naif, São Paulo, SP.

Kallinikos, J. et al. (2010), "A theory of digital objects", First Monday, available from: http://firstmonday.org/ojs/index. php/fm/article/view/3033/2564 (accessed 2017 Oct 2).

Lovink, G. (2016), On the Social Media Ideology, E-flux Journal, No. 75.

Machado, A. (2007), Arte e mídia, Zahar, Rio de Janeiro, RJ.
Manovich, L. (2001), The Language of New Media, MIT Press, Massachusetts.

McHugh, G. (2011), Post Internet: Notes on the internet and art, Link Editions, Brescia.

Santos, M. (2009), Direito autoral na era digital: impactos, controvérsias e possíveis soluções, Saraiva, São Paulo, SP.

Travisani, T. G. (2010), "Imagem em movimento na arte: o digital como processo criativo", available from: http://www. pucsp.br/revistaaurora/ed8_v_maio_2010/artigos/download/ed/7_artigo.pdf (accessed 2017 Oct 4).

Viertkant, A. (2010), "The image object post-internet", Nova York, available from: http://jstchillin.org/artie/pdf/The Image_Object_Post-Internet_a4.pdf (accessed 2017 Jul 10).

Received: 09 Dec 2017

Approved: 11 Jun 2018

DOI: 10.14488/BJOPM.2018.v15.n3.a7

How to cite: Villefort, W. (2018), "Digital Art on the Internet: the limits of the Brazilian Legal System and the Global Contemporary Thinking", Brazilian Journal of Operations \& Production Management, Vol. 15, No. 3, pp. 405-412, available from: https://bjopm.emnuvens.com.br/bjopm/article/view/422 (access year month day). 